\title{
Antidumping Protection and Productivity of Domestic Firms : A firm level analysis
}

J. Konings and $\mathrm{H}$. Vandenbussche

Discussion Paper 2007-28

\section{Département des Sciences Économiques de l'Université catholique de Louvain}




\title{
Antidumping Protection and Productivity of Domestic Firms: A firm level analysis
}

\author{
by Jozef Konings and Hylke Vandenbussche ${ }^{1}$
}

6 July 2007

\begin{abstract}
We analyze the relationship between Antidumping (AD) Protection and the productivity of EU domestic firms in import-competing industries. For this purpose we identify a panel of domestic firms between 1993 and 2003 that at some point during this period are affected by AD initiations. Using a difference-in-difference approach, we find that AD measures result in improvements of measured productivity for domestic firms. Total Factor Productivity (TFP) of protected firms increases by $2 \%$ in the short-run and by $5 \%$ to $13 \%$ in the long-run. However, there is substantial heterogeneity across firms. The effect of protection depends on the initial "distance-to-the-frontier firm" in the industry. While protection raises TFP of "laggard" domestic firms, it lowers TFP for "efficient" firms that operate close to the efficiency frontier. These results are consistent with recent theoretical work supporting the view that trade policy, under certain conditions, can induce technological catching-up. While this paper evaluates the effectiveness of AD policy it does not engage in a welfare analysis.
\end{abstract}

JEL-codes: F13, L 41, O30, C2

Keywords: Total Factor Productivity, Antidumping protection, technological catching-up

\footnotetext{
${ }^{1}$ Corresponding author: Hylke Vandenbussche, Department of Economics, Université catholique de Louvain, Place Montesquieu 3, 1348 Louvain-la-neuve, Belgium, T:+32(0)10 4741 37; F:+32(0) 104739 45; vandenbussche@core.ucl.ac.be and Jozef Konings, Department of Economics, Catholic University of Leuven, Naamsestraat 69, 3000 Leuven, Belgium, jozef.konings@econ.kuleuven.ac.be .
} 


\section{Antidumping Protection and Productivity of Domestic Firms ${ }^{2}$}

\section{Introduction}

There is a growing consensus that in many cases Antidumping (AD) policy is an industrial policy tool in disguise. Rather than being targeted at keeping 'unfair imports' out, it is often aimed at fostering the interests of inefficient domestic producers, irrespective of the intent of importers (Shin, $1998)^{3}$. In view of the industrial policy nature of AD measures, it is surprising that so little empirical work exists on measuring the effects of $\mathrm{AD}$ policy on domestic producers. A natural question that comes to mind is whether $\mathrm{AD}$ protection makes domestic firms more inefficient or whether domestic firms use the protection period as an adjustment period during which they engage in restructuring to become more productive by the time $\mathrm{AD}$ protection comes off. The recent availability of micro level data sets implies that this is a question that can now be analyzed.

Recent trade models like Melitz (2003) and Melitz and Ottaviano (2005) show that trade affects the average productivity in an industry by enabling more productive firms to take a higher market share and less productive firms to shrink. This paper is not concerned with these general equilibrium reallocation effects between firms, but instead focuses on how trade protection affects the evolution of within firm level productivity. Our analysis is partial equilibrium in nature and is mainly concerned with an evaluation of the effectiveness of AD policy for the domestic firms it is designed to foster.

There is a growing set of models that analyze how temporary protection can benefit importcompeting firms that are technologically lagging behind their foreign competitors, provided the protection is temporary (Matsuyama, 1990; Rodrik, 1992; Miyagiwa and Ohno, 1995 and Crowley,

\footnotetext{
${ }^{2}$ We thank the CEPR meeting 2007 in Tarragona, the 2007 EDP jamboree meeting at CORE-UCL, a CEPR-Productivity workshop 2006 at UCD Dublin, the EIIE conference in Slovenia 2005, a CEnter-Tilburg 2005 and CORE-Louvain seminar, the Midwest 2004 Spring meetings in Indianapolis, a World Bank seminar in 2004, the ETSG conference in Madrid, the LSE-IFS seminar on Productivity, and the Antidumping conference in Nottingham 2004. A special thanks goes to Jan De Loecker, Rachel Griffith, Jim Harrigan, Beata Javorcik, Richard Rogerson, Ray Riezman, Stephen Redding, Mary Amiti, Maurice Schiff, Johannes Van Biesebroeck, Joe Clougherty, Giordano Mion and Daniel Weiserbs.

${ }^{3}$ Shin (1998) argues that less than $10 \%$ of AD cases are about predatory intent, arguably the only economic rationale for protection against dumped imports.
} 
2006). These papers have explored how temporary tariffs can induce domestic firms to restructure and accelerate the adoption of more efficient production technologies. ${ }^{4}$ Using a continuous time model Miyagiwa and Ohno (MO) (1995) find that a domestic firm maximizing its inter-temporal profit function, will adopt a new technology faster under AD protection than under free trade. When we introduce cost heterogeneity as a novel feature into their model as we do in the theory section II of this paper, we find a new result i.e. that protection speeds up the adoption of new technology more for "laggard" firms than for "frontier" home firms. Put differently we find that the productivity gains resulting from protection are expected to be stronger for import-competing firms that are further away from the technology frontier.

This result can be usefully compared to recent work by Aghion et al. (2005) who showed that a reduction in product market competition reduces the technology gap in an industry. Also, Boone (2000) shows that for firms facing weak competition the incentive to innovate is stronger for less efficient firms. The intuition underlying this result is that with weak competition, strategic effects between firms are smaller than under tough competition. ${ }^{5}$ In line with these findings, this paper shows that trade protection, which lowers product market competition for domestic firms, has a bigger impact on "laggard" firms operating at a much lower productivity level than frontier firms. In the theory section we analyze the effects of trade protection on productivity and how it affects domestic prices. While the effect of a tariff on imports raises domestic prices, productivity improvements lowers domestic prices, hence the net effect on prices is ambiguous. In contrast, the model predicts that both trade protection and productivity improvements have a positive effect on domestic markups defined as the ratio of price over marginal cost.

This positive effect of AD protection on markups has been empirically confirmed in an earlier paper by Konings \& Vandenbussche (2005). In the current paper we focus on the effects of

\footnotetext{
${ }^{4}$ We use the word restructuring to refer to firms engaging in cost reducing investment, broadly defined and interpreted.

${ }^{5}$ Boone (2000) gives an intuitive example to explain his model. Compare a tournament B where it takes only one match to win versus a tournament $A$ where it takes 5 out of 9 matches to win. A faint player $\mathrm{j}$ will invest more effort in preparing for tournament B than for tournament $A$. In the more competitive tournament $A$, player $j$ has no chance of winning, knowing his opponent is much better.
} 
AD protection on firm level productivity. In doing so, we provide a number of theoretical and empirical results to show that the effect of $\mathrm{AD}$ we identify on measured productivity are not or at least not entirely attributed to price movements. Our data set includes all newly initiated European AD cases in three consecutive years 1996, 1997 and 1998. We turn to European data for two reasons. $\mathrm{AD}$ protection in Europe is of a more temporary nature than in the $\mathrm{US}^{6}$ and in Europe, in contrast to the US, non-listed firms also disclose firm level information on an annual basis.

Using a difference-in-difference (DD) approach our findings confirm that firms protected by AD measures on average have higher productivity gains than firms in various control groups. Also, our empirical findings indicate that $\mathrm{AD}$ protection results in relatively stronger productivity gains for "laggard" firms than for "frontier" firms. We identify firms in the European Union (EU) ${ }^{7}$ in sectors directly affected by the AD policy and use their corresponding firm-level company accounts data to obtain output and input measures for the period 1993 to 2003 to estimate Total Factor Productivity (TFP) before and after AD protection. We estimate TFP using the approach proposed by Olley and Pakes (1996) to correct for exit (sample selection) of firms and the endogeneity of input factors.

In the $\mathrm{DD}$ approach evaluating the effect of $\mathrm{AD}$ protection we use two different control groups. $\mathrm{A}$ first control group consists of all firms that filed for $\mathrm{AD}$ protection but did not receive it since the outcome of the case was 'termination' without protection. But since the firms in this control group belong to industries that filed for protection, there could be selection at work in terms of which industries receive positive rulings versus negative rulings. To control for endogeneity of AD protection and potential selection effects, we turn to a second control group by constructing a 'matched' control group of firms inspired by the matched sampling techniques developed by Heckman et al. (1997). For this, we estimate the probability of AD protection using a multi-nominal

\footnotetext{
${ }^{6}$ Europe has always had a Sunset Clause limiting the protection period to 5 years. The US adopted the Sunset clause much later after the Uruguay Round.

${ }^{7}$ During the period of our analysis the European Union consisted of 15 countries.
} 
logit model to "match" the protected firms to firms in similar sectors but that never filed an AD case nor received protection ${ }^{8}$.

Independent of which control group we use in the DD approach, all estimates suggest that domestic firms improve their measured productivity during the period of AD protection. Protection increases TFP levels between 5 and 13\% depending on the specification used and on the "distanceto-the-frontier firm".

A logical question following our analysis is where do the productivity improvements come from. Our firm level data shows evidence of labor shedding, increased R\&D spending and an increase in investment in fixed assets after $\mathrm{AD}$ protection. But there are other channels through which productivity can be improved that we can not measure. Bernard et al. (2006) argue that plants in import-competing sectors facing tough competition from abroad are likely to change their output mix towards products with more capital and more skilled labor mix. From previous literature we know that the demand for $\mathrm{AD}$ protection typically arises in sectors facing strong import-competition (Konings and Vandenbussche, 2005). While "product switching" is a very likely source of productivity improvement our data does not hold information on that. Also, our data does not have information of skilled versus unskilled labor preventing us to analyze skill upgrading in production. We do find that average wages at the firm level go up after protection which could be consistent with an increase in the skill mix. However increased wages may also be consistent with rent-sharing where some of the increase in profits resulting from protection are shared with workers in the form of a higher wage. Whatever the correct interpretation, in both cases productivity is likely to go up. An increase in the skill mix is likely to boost productivity, just like a wage increase for existing workers is likely to induce more effort since workers stand to loose more when fired. Another channel through which productivity improvements may arise is outsourcing as documented by Feenstra and Hanson (1999). They show that firms respond to import competition by moving non-

\footnotetext{
${ }^{8}$ In an earlier version we also experimented with a third control group consisting of non-EU firms (Norway, Switzerland, Central and East European countries) operating in the same sectors as the sectors affected by AD, but outside the EU. Also, with this third control group we obtained qualitatively similar results as those report in the current paper.
} 
skilled activities abroad and shift local employment more towards skilled workers. This would be consistent with shedding unskilled labor at home going hand in hand with investment in tangible and intangible assets which also translates into higher productivity.

While we find that trade protection can raise productivity of the firms affected by the policy, Levinsohn (1993), Harrison (1994), Tybout and Westbrook (1995), Pavcnik (2002) and more recently Trefler (2004) or Amiti and Konings (2007) find that trade liberalization raises the productivity of domestic firms in developing countries. These results are not necessarily in contradiction with ours. Our analysis is not meant to engage in an evaluation of the overall welfare effects of $\mathrm{AD}$ policy. In fact the overall welfare effects could well be negative since $\mathrm{AD}$ protection may prevent a process of (re)allocative efficiency in the importing country to take place. The results in this paper are therefore best interpreted as an evaluation of the effectiveness of AD policy on domestic firm performance. ${ }^{9}$

In the next section we present a theoretical framework that will help us to understand some of the economic mechanisms at work. In section III we discuss our data and in section IV we present the empirical methodology and results. Section V concludes.

\section{Theoretical Framework}

Miyagiwa and Ohno (1995) show that temporary tariff protection with an exogenous ending date results in earlier adoption of new technology by the protected firms compared to free trade. The adoption of new production techniques is modeled as a reduction in marginal cost which corresponds to an increase in productivity. The two crucial features under which the Miyagiwa and Ohno (MO) (1995) result were derived are a fixed cost of technology adoption that falls over time and a credible ending date of protection. Consider a home firm, $(\mathrm{H})$ and a foreign firm (F) that compete in quantity in the home market in every period $\mathrm{t}$ with $\mathrm{t} \in\left[0,+\infty\left[\right.\right.$ where demand is $P=P\left(q^{H}, q^{F}\right)$. Assume that a

\footnotetext{
${ }^{9}$ Gallaway et al. (1999) have estimated the welfare cost of US AD and Countervailing Duty law at \$4 billion a year. Vandenbussche and Zanardi (2006) find that the new and tough users of AD have their total annual imports decreased by $8.9 \%$ as a result of their $\mathrm{AD}$ actions.
} 
cost-reducing technology became available sometime in the past, which by $t=0$ the foreign firm has adopted, yielding a marginal cost of production of $c_{\theta}$. The home firm is a technological laggard and operates at a higher marginal cost of production $c_{\bar{\theta}}$ where $c_{\bar{\theta}}>c_{\underline{\theta}}$. Without loss of generality one can set the foreign firm's cost $c_{\underline{\theta}}=0$ and simplify notation by writing $c_{\bar{\theta}}$ as $\mathrm{c}>0$. The lower marginal production cost of the foreign firm will result in a lower equilibrium price for that firm compared to the home firm, which allows the home firm to apply for antidumping protection. ${ }^{10}$ Adoption of new technology at time $\mathrm{t}=\mathrm{t}^{*}$ costs the home firm a one-time fixed cost, denoted by $\mathrm{k}(\mathrm{t})$, which falls over time at a decreasing rate. Note that the home firm has an incentive to adopt the new technology since $\Pi_{\underline{\theta}}^{H}>\Pi^{H} \bar{\theta}$. In each period, the home firm balances the gains from early adoption against higher costs of early adoption and chooses the timing accordingly. When the home government decides on protection, it installs an AD-duty $\tau$ per unit of import of the foreign firm. Given that protection affects profits, the profitability of early technology adoption might be altered and hence the timing of restructuring may change as compared to free trade. The temporary character of ADprotection lies in the fact that after an exogenously fixed duration of protection $\mathrm{T}$, free trade is back in place. Also it is assumed that the optimal date of technology adoption, $t^{*}$, takes places before the end of the protection period $\mathrm{T}$.

The optimal timing of cost reducing investment by the Home firm, $t^{*}$, is chosen by maximizing the following inter-temporal profit function (MO, 1995)

$$
\int_{0}^{t^{*}} e^{-r v} \Pi^{H} \bar{\theta} d v+\int_{t^{*}}^{T} e^{-r v} \Pi^{H}{ }_{\underline{\theta}} d v+\int_{T}^{+\infty} e^{-r v} \Pi^{H}{ }_{F T, \underline{\theta}} d v-e^{-r t_{\tau}} k\left(t^{*}\right)
$$

where $r$ denotes a given interest rate. The first and second integral in (1) represent the present discounted sum of profits before and after the adoption of new technology, whereas the third integral is the discounted sum of profits after protection. The last term in (1) is the present discounted value

\footnotetext{
${ }^{10}$ In addition to dumping determination, injury determination is required for which various criteria are used in the EU decision making process. Foreign price-undercutting in the domestic market is one of the most important injury criteria in EU Antidumping cases (Veugelers and Vandenbussche, 1999).
} 
of the fixed adoption cost. MO (1995) have shown that the solution to (1), $t^{*}$ is given by the following equilibrium condition

$$
r k(t)-k^{\prime}(t)=\Pi_{\underline{\theta}}^{H}-\Pi^{H}{ }_{\bar{\theta}}
$$

This expression equates the marginal cost to the marginal benefit of technology adoption at time $t$. The left hand side represents the marginal benefit of waiting one period: the home firm benefits from investing the money $\mathrm{k}(\mathrm{t})$ in an alternative use and earns $\mathrm{r} . \mathrm{k}(\mathrm{t})$ and saves on the cost of technology adoption $\mathrm{k}^{\prime}(\mathrm{t})$ by waiting one more period. The right hand side of the equation gives the marginal benefit of adopting the new technology now.

Duty protection speeds up the timing of technology adoption compared to free trade since the marginal benefit of technology adoption is an increasing function of the duty:

$$
\frac{\partial\left(\Pi^{H}{ }_{\underline{\theta}}-\Pi^{H} \bar{\theta}\right)}{\partial \tau}>0
$$

From the expression in (3) we can now introduce a novel feature into the model by allowing for cost heterogeneity among firms. This yields the new result that a duty on imports has different effects depending on the efficiency level of the home firm. To see this take the cross-derivative of (3) with respect to the home firm's marginal cost of production. This derivative is positive, implying that the more inefficient the home firm, the more an AD duty speeds up the adoption of new technology. Or in other words, AD protection has a larger effect on "laggard" home firms than on "frontier" home firms that operate at an efficiency level closer to the technology frontier.

$$
\frac{\partial}{\partial c}\left(\frac{\partial\left(\Pi^{H}{ }_{\theta}-\Pi^{H} \bar{\theta}\right)}{\partial \tau}\right)>0
$$

A prominent question is what happens to the prices and markups for domestic firms. From the above model it is easy to verify that a tariff on foreign imports raises the domestic price, however productivity improvements through restructuring lowers prices, hence the net effect on domestic prices is ambiguous and depends on the size of the tariff and the magnitude of the productivity improvement. In contrast, in terms of markups it can be verified that both a tariff and a productivity 
improvement both have a positive effect on markups. Therefore the model shows that an increase in markups and an increase in productivity can go hand in hand:

$\frac{\partial P}{\partial t}>0 ; \frac{\partial P}{\partial c}>0 ; \frac{\partial(P / c)}{\partial t}>0 ; \frac{\partial(P / c)}{\partial c}<0$

In an earlier paper Konings \& Vandenbussche (2005) provided empirical evidence that markups indeed rise after $\mathrm{AD}$ protection which fully corresponds with the model above. The current paper investigates the effect $\mathrm{AD}$ protection on within firm productivity. This question while highly relevant is a delicate one since we do not observe prices. Similar to Trefler (2004) in what follows we turn to unit values as a proxy for sales prices. Any change in the prices resulting from ADprotection would show up in the unit values of intra-European trade flows of the products (HS 8 digit) protected by a 'common' AD-duty.

It is not our intention to structurally test the above framework, rather it is a useful guideline for interpreting our empirical evaluation of $\mathrm{AD}$ protection on firm behavior. Because we have no information on the timing of adoption of new technology and the type of technology, we interpret technology adoption in the above framework as general efforts of firms to engage in efficiency enhancing restructuring. It is also for this reason that we will focus on firm level productivity, which is regarded as a good proxy for technology (Keller, 2004).

\section{The Data}

An important innovation of our work is that we use firm-level data to test for the relationship between AD-protection and productivity of the protected firms. An AD-case typically involves an investigation of the evolution of imports and import prices from countries that are accused of dumping by the import-competing EU industry. The dumping complaint is investigated by the EU Commission and can result in 'Protection' or in 'Termination'. ${ }^{11}$ If protection is decided upon, a final $\mathrm{AD}$ duty is imposed on the 'dumped' imports to protect all the firms in the EU import-

\footnotetext{
${ }^{11}$ In the U.S. many cases end in "withdrawals" by the complaining industry as shown by Prusa (1992). This is hardly ever the case in the EU where a "Termination" usually refers to a negative ruling by the EU Commission.
} 
competing industry. Protection can also be implemented in the form of price-undertakings. This involves a voluntary price increase offered by the alleged dumpers to offset the injury to the EU import-competing industry (EU regulation 386/94). Case reports reveal very little information on the details of price-undertakings agreed upon between the EU Commission and individual exporters. While in some $\mathrm{AD}$ cases, all exporters from a particular country are subject to a price-undertaking, in other cases a mixture of duties and price-undertakings applies. When the Commission decides to 'terminate' the $\mathrm{AD}$ case, the dumping complaint is rejected and the EU industry does not get further import relief.

For the purpose of analyzing the relationship between AD-protection and productivity of EU producers, we identify 4,799 EU firms that operate in the same sector as the dumped products. We obtain their company accounts from a commercial database sold under the name of AMADEUS ${ }^{12}$ that runs from 1993-2003. This is a pan-European set of company accounts with harmonized entries for all European enterprises on an annual basis.

In Table 1 we give an overview of all the new $\mathrm{AD}$ cases $^{13}$ that were initiated in 1996, 1997 and 1998 and for which we could retrieve all the variables from the company accounts required for our analysis. In total, 29 new AD investigations were initiated when we count by product group which corresponds to 81 cases when we count cases by defending country. For each case we list the year of initiation, the corresponding 4 digit industry NACE revision 1, the average number of 8-digit HS codes involved, ${ }^{14}$ the year of decision, the average duty and the importing countries involved. We collect firm-level data for the EU import-competing sector based on the 4-digit NACE sector the product under investigation was classified in. The NACE classification is a detailed industry classification used by the European Union with 622 different 4-digit codes. One notable advantage

\footnotetext{
${ }^{12}$ AMADEUS is a commercial dataset that can usefully be compared to COMPUSTAT data in the US, but in addition to listed firms, AMADEUS also includes unlisted firms. The AMADEUS data set has increasingly been used in other academic work. Recent examples include Budd, Konings and Slaughter (2005) and Helpman, Melitz and Yeaple (2004).

13 'New' implies that these cases were not subject to protection when the case was initiated.

${ }^{14}$ The Harmonized System (HS) is the product classification used by the EU in the trade statistics.
} 
of this approach is that for the DD estimations, a control group can be found by "matching" protected sectors with other NACE 4-digit sectors that were never subject to AD filings.

In 17 of the new cases (by product group), the outcome was protection, usually in the form of an $\mathrm{AD}$ duty but in some protection cases, price-undertakings were also offered and accepted by the EU Commission. Duties range between $13 \%$ and $82 \%$, with an average duty of $27 \%$. In 12 other cases (by product group), the EU Commission did not grant import relief, after which the case was terminated.

A number of remarks are in order here. In dealing with the cases we came across a number of overlaps. For example, in 1996 the case involving "Synthetic Fibre Ropes" was initiated against India but was terminated without protection later that year. The next year, in 1997, a new petition by the EU producers of "Synthetic Fibre Ropes" was initiated against India and this time round the EU Commission decided to grant protection from 1998 onwards. This implies that the EU firms in the import-competing sector were protected from 1998 onwards. For this particular case, we let the period before protection run from 1993-1997 and the period after protection from 1998 onwards. Another type of overlap arose when two different cases map in the same NACE 4-digit. A good example is "Cotton Fabrics", a case initiated in 1996 and again in 1997, both resulting in a termination, which maps into the same NACE sector as "Woven Glass Fibre", initiated at the end of 1997, also ending in a termination ${ }^{15}$. After dealing with the overlaps described above, we still have 23 different AD cases of which 16 ended in Protection and 7 were terminated. In view of the large number of AD-cases included in the analysis, it is not our intention to engage in an in depth industry-by-industry analysis. Our purpose here is to present evidence on productivity estimates of a large set of cases.

For clarification, we point out that when the EU Commission decides to impose a duty, it applies to all EU-member states and can be compared to a 'common tariff' protecting the EU import-

\footnotetext{
${ }^{15}$ One other type of overlaps occurred i.e. a case that first got terminated but in a later year ended in protection. For that case, we considered the sector as protected from the moment the product belonging to that sector received protection.
} 
competing sector against imports from the dumping countries. AD protection remains in place for five consecutive years, after which AD-measures in principle come off. However, industries have the option to initiate an "expiry review" case. Such an "expiry" case can be initiated 3 months before the ending of protection, provided there are indications that when the protection comes off, injury and dumping would continue. The law stipulates that a decision has to be reached within a year after the initiation of an expiry review, during which the protection continues. ${ }^{16}$ If affirmative, the industry obtains 5 more years of protection. For the cases included in our analysis, in 4 of them, an expiry review was initiated towards the end of their protection period which is documented in Table 1. For example, "Seamless steel tubes", a case originally initiated in 1996, whose protection period normally ended in 2002, applied for an expiry review which was decided affirmatively in 2004. Another expiry review case ending in protection is the 1997 case "Synthetic Fibre Ropes". In two other cases, notably the 1996 case "Bed linen" and the 1998 case "Steel Stranded Ropes and Cables", an expiry review was initiated but the Commission ruled negatively and the protection was ended. Expiry review cases are likely to involve domestic firms that engaged less in restructuring and therefore renew their demand for protection. Hence we expect to find less productivity improvements in those cases. We conducted our analysis both with and without expiry review cases. Including them in our analysis moderates the average productivity increase that we find. In fact, a separate productivity analysis for the four expiry review cases reveals negative but insignificant productivity effects of $\mathrm{AD}$ protection.

\section{Empirical Methodology and Results}

\section{IV.1. Estimating Total Factor Productivity (TFP)}

\footnotetext{
${ }^{16}$ The latest EU AD law is Regulation 384/96.
} 
We estimate Total Factor Productivity (TFP) using our firm-level data for firms operating in each 4-digit NACE industry affected by AD initiations. Let us describe firm i's technology at time t by a Cobb-Douglas production function ${ }^{17}$ :

$$
y_{i t}=\beta_{0}+\beta_{l} l_{i t}+\beta_{k} k_{i t}+\eta_{i t}
$$

where $y_{i t}$, denotes the $\log$ of value $\operatorname{added}^{18}$ at the firm level, deflated by 4 digit sector-specific producer price indices, $l_{i t}$ denotes the log of labor and $k_{i t}$, denotes the log of real capital measured by fixed tangible assets deflated by a capital price deflator ${ }^{19}$ and $\eta_{i t}$ is the residual. We use the OlleyPakes methodology to estimate equation (6). The estimation procedure takes account of the simultaneity between input choices and productivity shocks, as well as sample selection bias. This allows us to estimate the coefficients in the production function $(6),{ }_{1}$ and ${ }_{-}$, consistently for each product group (see appendix for details). Using these estimates we define the log of TFP of firm i at time $t$ denoted by $t f p_{i t}$, as the residual of the production function, or

$$
t f p_{i t}=y_{i t}-\hat{\beta}_{l} l_{i t}-\hat{\beta}_{k} k_{i t}
$$

Summary statistics of the variables used for estimating the production function in (6) and the estimated input coefficients obtained from estimating (6) with Olley-Pakes and with OLS are reported in the appendix. As expected the labor coefficient is over-estimated under OLS, while the capital coefficient is under-estimated.

\footnotetext{
${ }^{17}$ A RESET test was applied but did not reject the use of a Cobb-Douglas production function suggesting that this assumption fits the data reasonably. We thank Daniel Weiserbs for this suggestion.

${ }^{18}$ We use a valued added production function as in Olley-Pakes, rather than a gross output function for a number of reasons. First, by using a value added production function we avoid finding a good material inputs price deflator, which is difficult to find as we do not know from our data what type of materials are being used in the production process. Second, by not including material inputs as a regressor we avoid a potential endogeneity problem with material inputs as they are most likely highly correlated with a productivity shock. Third, depending on the specific accounting legislation in the different EU countries where our firms are located, the reporting requirements regarding sales and material costs vary, which results in missing observations on sales and material costs in a number of firms. However, value added, defined as sales minus material costs is reported in most firms and is hence used as our left hand side variable. For those countries that do not report material inputs we used the gross value added reported by the firm. This consists of profit/(loss + depreciation+interest costs + material costs + wage costs).

${ }^{19}$ The capital price deflator is country specific and obtained from the Ameco database of the EU.
} 
The revenue based TFP estimates from equation (6) are also likely to reflect differences in prices. Deflating firm level nominal value added with an industry wide price deflator would be fine if all firms are producing a single and homogeneous product, so that they all face the same prices. However, with differentiated and multiple products this is unlikely the case (see Klette and Griliches, 1996; Levinsohn and Melitz, 2002 and Katayama, Lu and Tybout, 2003 for a discussion). In addition, measured productivity can change as a result of changes in the product mix over time (Bernard, Redding and Schott, 2006) ${ }^{20}$. We therefore will report a number of robustness checks. We report separate estimates for single versus multiple product firms and we report results where we use instead of a 4-digit industry producer deflator a deflator constructed from the unit values of the products that were involved in an AD initiation. We also analyze the evolution of the unit values of the products involved in an $\mathrm{AD}$ initiation to assess whether a potential price effect might dominate the measurement of TFP. Our results clearly show that the productivity improvements are not a mere price effect. In fact, a recent paper by Mairesse and Jaumandreu (2005) on a panel of firms for which they have individual firm output prices find that whether value added is deflated with an industry output-price index, with an individual firm-output price index or not at all makes little difference for the estimation of the coefficients in the production function. This suggests the customary practice of simply deflating output measures (sales, value added etc.) by industry output-price indices when estimating production functions is an acceptable approach.

\section{IV.2 Evaluating the Effects of Antidumping-Protection}

\section{IV.2.1. Difference-in-Difference (DD) Equations}

A Difference-in-Difference (DD) approach consists of comparing TFP of the 'treated' group, i.e. the firms that got $\mathrm{AD}$ protection, to a control group of firms. A first natural candidate control

\footnotetext{
${ }^{20}$ Other potential biases emerge from the way in which input factors are measured, e.g. the labor input is measured in terms of number of employees rather than hours worked. Van Biesebroek (2003) compares different methods for estimating production functions on data characterized by known measurement errors and finds that the semi-parametric methods, like the O-P one we use here, is least sensitive to measurement error when estimating productivity.
} 
group for the protection cases is clearly the termination cases. Termination cases involve firms in sectors that filed for AD protection but did not get it. We also turn to a second control group inspired by the matched sampling techniques developed by Heckman et al. (1997). To identify a matched control group we first estimate a multi-nominal logit model at the 4-digit NACE level. The variables included in our multi-nominal logit model are similar to the model of Blonigen and Park (2004). The data that we use includes information on filings and outcomes of all the AD cases at the 4-digit NACE level between 1995 and 2002. Our dependent variable can take three outcomes, 'no filing', 'filing that resulted in a termination' and 'filing that resulted in protection'. As explanatory variables we include 'lagged import penetration' defined as yearly imports from outside the EU into the 4digit NACE sector over the sum of domestic production in the EU in the NACE 4 digit and imports from outside the EU. ${ }^{21}$ We also include 'lagged industry employment', 'EU GDP growth' and the 'number of previous AD filings' in the NACE sector up to year t-1, where we count the number of previous AD filings from 1985 onwards. To control for pre-policy trends in productivity we also include the 'growth in labor productivity' as an additional variable. The inclusion of this variable is to account for the fact that the DD estimator assumptions may be violated if pre-treatment characteristics that are thought to be associated with the dynamics of the outcome variable are unbalanced between the treated and the untreated group (Abadie, 2005). ${ }^{22}$

The "matched" control group consists of sectors with a similar probability of protection but that never had protection. ${ }^{23}$. This resulted in a control group of 4,678 firms. ${ }^{24}$ We now test the following DD specification:

\footnotetext{
${ }^{21}$ Trade data come from EUROSTAT and production data from PRODCOM.

22 The results of the multi-nominal logit are not shown here for brevity but more details are provided in the working paper Konings and Vandenbussche (2007) and is downloadable from www.econ.kuleuven.be/public/ndbad40.

${ }_{23}$ Based on this we find that $69 \%$ of all NACE 4-digit sectors never faced AD protection. The matched control group consists of sectors that never received AD protection but with a predicted probability that was at least equal to the $75^{\text {th }}$ percentile of the predicted probability of protection in the group of sectors that did receive AD protection. In addition we impose that average values of the explanatory variables - used in the multi-nominal logit model - of the matched group are statistically similar to the treatment group, the so called balancing property.

${ }^{24}$ In our working paper version we additionally report the NACE sectors in the "matched" control group with the OLS and O-P estimates of the labor and capital coefficient in the production function per sector.
} 


$$
\begin{aligned}
& t f p_{i j t}=\alpha_{0}+\alpha_{1} A D_{-} \text {EFFECT }_{j}+\alpha_{2} \text { EVER_PROTECTION }_{j} \\
& +\alpha_{3} Y E A R \_D U M M I E S+\alpha_{4} \text { COUNTRY_DUMMIES }+\alpha_{5} Y E A R X C O U N T R Y+\varepsilon_{i t}
\end{aligned}
$$

EVER_PROTECTION is a dummy that takes a value of 1 for the entire period, if a firm i belonging to sector $\mathrm{j}$ ever got protection during the period of analysis. The EVER_PROTECTION dummy captures all time-invariant differences between the group of protected firms in protected sectors and the control group of firms in unprotected sectors and hence controls for the fact that firms that receive protection may have some unobserved specific characteristics. The YEAR dummies capture for both the firms in the control group as well as the firms that received AD-protection any time effect on TFP, common to all firms, due to e.g. business cycle effects, demand shocks or other common macro shocks. The COUNTRY dummies control for location specific effects for firms in particular countries inside the EU. We also interact these location specific fixed effects with the year effects to capture differences in shocks across various EU countries. Finally the term AD_EFFECT is a dummy equal to 1 for the years following protection and zero in the years before but only for the group of firms in sectors $\mathrm{j}$ that got protection. For all other firms in the control group the dummy is zero. This AD_EFFECT captures the essence of the DD approach since it estimates the differential effect that AD-policy has on protected firms versus firms in the various control groups.

\section{IV.2.2. Results}

In Table 2 we report the results of various DD specifications where we first use the termination cases (columns 1 to 3 ) and then the matched counterfactual (column 4, 5) as respective control groups. In all specifications the main coefficient of interest on AD_EFFECT is positive and statistically significant with long-run estimates ranging between 7 and 13\%. In columns (3) and (5) we include lagged TFP as an additional regressor in order to control for hidden dynamics. The short- 
run estimates in these specifications range between 1.7 and $1.9 \%^{25}$ and given that the lagged dependent variable is statistically significant and estimated at 0.81 , the corresponding long-run impact on TFP is estimated at $10 \%$ (or $0.019 /(1-0.81)$ ). Interestingly, the results of AD protection on productivity are very similar across the various specifications and irrespective of the control group. This suggests that firms in Termination cases are a good counterfactual and that the potential selection effects at work are not too serious.

In order to check whether the positive effect of $\mathrm{AD}$ on measured productivity is driven by a price effect we carry out a number of experiments. First, in column 2 of Table 2 we use the unit values of the products involved in the AD case as a deflator instead of a 4-digit industry deflator. These unit values stem from intra-EU trade flows of the 8-digit HS goods involved in AD initiations. We retrieve the unit values over the same period as our firm level data and construct an index for deflation purposes. We use unit values as a proxy for prices as in Trefler (2004) since we measure unit values at a very detailed level of dis-aggregation, the HS8 digit product code. Changes in unit values within an HS8 item are likely to reflect changes in prices. The coefficient on the ADEFFECT when using unit values is very similar to the PPI deflator and close to $7 \%$. Note that for the matched control group we can not use unit values as a deflator since different products than the AD ones are involved in the matched sectors which is why we only use the 4 digit PPI deflators. Second, we analyze the evolution of unit values to check whether prices increased after AD-protection. To this end, we estimate a similar difference-in-difference equation, but instead of analyzing the effects on firm level TFP we analyze the effects on the log of product level prices, proxied by the unit values of intra-EU imports. In particular we estimate the following equation and use the 8 digit HS unit values of goods in termination cases as our control.

\footnotetext{
${ }^{25}$ Including the four expiry review cases in the specification in column 3 of Table 4 moderates the short-run productivity effects to $1.6 \%$ instead of $1.9 \%$. A separate productivity analysis for the domestic firms in expiry review cases yields a negative but insignificant coefficient on the AD-Effect.
} 
$\ln$ price $_{k t}=\alpha_{0}+\alpha_{1}$ EVERPROTECT $+\alpha_{2}$ TIME $+\alpha_{3} A D-P R I C E-E F F E C T+\varepsilon_{k t}$

Where the dependent variable is the $\log$ of the unit values of intra-EU imports of good $\mathrm{k}$, EVERPROTECT is a dummy that equals 1 in every period if a product was ever protected by AD and with a value of zero for all goods that never received protection from imports coming from outside the EU, while TIME gives all goods a value of 1 from the period of protection onwards and AD-PRICE-EFFECT is the interaction between EVERPROTECT and TIME. The coefficient on the interaction effect is the coefficient of interest and indicates whether price movements of protected goods evolved differently than for those goods in terminated AD cases that never received protection.

The results in Table 3 show that there is little evidence of strong price increases after protection. In column (1) we find no significant increase in prices as a result of AD. In column (2) where we include a lagged dependent variable to control for serial correlation the AD-PRICE-Effect remains insignificant. Interacting the AD-PRICE-EFFECT with time dummies as we do in columns (3) and (4) shows that price effects in all years are insignificant, with the sole exception of the fourth year after $\mathrm{AD}$ protection where there is a positive but only marginally significant effect on prices. Our results seem consistent with the findings of Liebman (2006) who fails to find a significant increase in U.S. steel prices after a safeguard was put in place by the US government. Liebman (2006) using disaggregated product-level monthly panel data for steel finds that U.S. prices were much more affected by business cycle conditions and industry rationalization than by the safeguard protection imposed on imports of steel from abroad. The empirical results on prices also confirm the predictions of the theoretical model discussed in section II where the joint effect of protection and the productivity improvements that it triggers yield an ambiguous effect on domestic prices. These results are not in contrast to Prusa (1997) who shows that AD protection raises the unit values of foreign imported goods. The asymmetric response of foreign versus domestic prices seems to 
suggest that $\mathrm{AD}$ protection forces the foreign price to align on the price of domestic products to close the price gap between foreign and domestic prices. Also, the small amount of exit that is observed during the period of protection (less than 3\%) is too small to increase market concentration for firms to gain more pricing power.

\section{IV.2.3. Distance-to the-Frontier heterogeneity}

As discussed in section II, theoretically there are reasons to suspect that the effects of protection on productivity may differ across firms. In particular, we expect the effect of protection on productivity to be stronger for less efficient domestic firms. To get at this idea, we introduce firm heterogeneity within the group of protected firms, in terms of their initial "distance to the frontier firm". We define the initial "distance-to-the-frontier" for each firm i as the ratio of TFP over the productivity in the frontier firm $\mathrm{j}$ which is the firm with the highest TFP in the same NACE 4 digit industry, in the year of the initiation of the AD case.:

$$
\operatorname{DISTANCE}_{i j}=\frac{T F P_{i}}{\operatorname{Max}_{j}(T F P)}
$$

A distance of 1 implies that a particular firm is as efficient as the frontier firm, while a distance of 0 refers to a "laggard" with the lowest possible efficiency level compared to the frontier firm.

In Table 4 we show the results of our DD specification, but now including the initial 'DISTANCE' variable and the interaction of that variable with our previous treatment variable AD_EFFECT X DISTANCE. Again we use both the firms in termination cases and the matched firms as a control. The AD-EFFECT in all specifications is positive and significant. As expected the interaction of the AD-EFFECT with DISTANCE is negative and statistically significant. This confirms the notion that the further away a firm is from the EU frontier firm in its corresponding sector, the stronger the impact of protection. Or in other words, the positive effect of AD protection 
on productivity is smaller for firms closer to the efficiency frontier. The median distance of the EU firms in protected sectors is $23 \%$ with a standard deviation of $16 \%$. Or put differently, the median firm is only about one fourth as efficient as the most efficient firm in its industry. This suggests that the distribution of productivity in an industry is very skewed with a few very efficient firms that have productivity levels far higher than the median firm. Based on the results in column 1 of Table 4, we can say that while the coefficient on the AD_EFFECT is positive and equal to 0.063 , the interaction effect is negative -0.110 . Hence the overall short-run AD_EFFECT of protection on productivity for "median distance to the frontier firm" in the sample is positive and around $3.8 \%$ $(0.063-(0.110 \times 0.23))$. Given that we also included $\mathrm{tfp}_{\mathrm{t}-1}$ as a regressor with a significant coefficient of 0.703 we can also obtain a long-run estimate of the effect of AD on TFP levels of $12 \%(0.038 /(1$ 0.703)). We obtain similar results for the other specifications when unit values are used or the matched control group.

\section{IV.2.4. Single-Product firms versus Multi-Product firms}

One of the problems we face in our analysis is that a number of domestic firms in our analysis operate in different sectors and produce multiple products. One way we controlled for this in our analysis thus far is that we only included firms in the analysis whose "primary sector of activity" corresponds with the import-competing sector that the dumped products belong to. Or put differently, we included firms whose operations predominantly belong to the sector filing for AD protection. However, what we have not controlled for up to this point is that a substantial number of firms are also active in other 4-digit NACE sector. We would expect AD protection to have more of an effect on the productivity of those firms whose primary and only line of activity falls in the same NACE sector as the AD activity. Therefore we classify firms on the basis of their number of NACE codes. A firm that is active in only one NACE sector is defined as a single product firm, whereas a firm active in two NACE sectors or more, is considered a multi-product firm. This is obviously a 
rough way of classifying single versus multiple product firms, but even with this rough proxy we would expect the results to be stronger on the single product firms.

In Table 4 we report the results of a DD approach now distinguishing between single and multiple activity firms in the treatment and in the control groups. ${ }^{26}$ Independent of the control group, the AD_EFFECT is stronger in the case of single activity firms than for multi-activity firms, which confirms our expectation. Based on the coefficients in column 3 of Table 4 we find the increase in short-run productivity for the median single-product firms ${ }^{27}$ to be $3.9 \%$ and the long-run effect to be $12 \%$ when terminations are used as a control while for multi-product firms we fail to find a significant effect. When using the matched control group, we find for the single activity firms the short-run effect of $\mathrm{AD}$ protection on TFP levels to be $1.3 \%$ and the long-run effect to be $5 \%$. In the case of multi-product firms the significance of the AD effect drops from $1 \%$ significance to $10 \%$ significance and the coefficient and the magnitude of the coefficient on the AD effect is reduced by half.

\section{IV.2.5. Mis-specified Dynamics}

Recently Bertrand et al. (2004) argues that standard DD approaches may result in biased estimates of the treatment effect due to mis-specified dynamics. They show in simulations that including a simple autocorrection process like we do in Tables 3 and 4, by including a lagged dependent variable, does not necessarily perform well and may still bias the estimates as the dynamic process may still be mis-specified. One simple way to correct for that proposed by Bertrand et al (2004) is to collapse the time series information into a pre- and post- period. We report two further experiments using this approach. First, we compute the average TFP pre-AD protection and the average TFP post-AD protection. In doing so, we average out any temporary shock in TFP. Second, we turn to a long-run differences approach similar to the approach used by Trefler (2004)

\footnotetext{
${ }^{26}$ Note that the number of observations used in this analysis is smaller, because the data for French firms do not distinguish between single and multiple product firms so we excluded data of French firms.

${ }^{27}$ The median distance to the frontier firm for single product firms is the same as for multiple product firms.
} 
where we compare TFP growth in the pre- and post- AD period. We compute TFP growth as in Trefler (2004) by the annualized 5-year long run change in log TFP, where initial TFP is taken as the level of TFP prior to protection ${ }^{28}$.

The results of this approach are shown in the first four columns of Table 5. In column (1) and (2) we find an AD-treatment effect of $13.2 \%$ and when we interacted with distance, we get an effect of $12.5 \%$ for the median firm in our sample. These results are very similar to the ones we obtained earlier.

In columns 3 and 4 of Table 5 we analyze the effects of AD protection on TFP growth. We find that TFP growth increases by $1.6 \%$ as a result of AD. Allowing for firm heterogeneity in column 4 by interacting the AD-Effect with distance and applying it to the median firm yields an effect of $\mathrm{AD}$ protection of TFP growth of $2 \%$. We can interpret these results as the short run effect of AD protection on TFP, similar as the results reported in table 2 where we included lagged TFP.

Finally in column 5 of Table 5 we turn back to our original firm level panel used earlier and interact the AD-Effect with year dummies to check whether the treatment effect takes some time before it affects TFP. It can be noted that productivity increases occur each year with the larger effects occurring towards the end of the five year AD protection period. To what extent the productivity continues to improve when protection comes off is an equally interesting question but one we can not address given the time span that we have. Further research will have to show to what extent the productivity improvements appear to be permanent or temporary in nature.

\section{IV.2.6. Digging Deeper: Where do Productivity Improvements come from?}

Finally the question can be raised where the productivity improvements come from. Given that we have estimated TFP after taking into account variation in input factors, the increase in TFP

\footnotetext{
${ }^{28}$ For computing the long difference prior to protection it was not possible to compute the 5-year long difference for the cases initiated in 1996 since our data only started in 1993, so we used the 3-year long difference instead, but recomputed on an annual basis by dividing through the number of years.
} 
that we measure here is unlikely to be explained by a scale effect, but seems rather to be consistent with the idea that firms have more incentives to engage in cost reducing restructuring efforts once they receive temporary protection. Also, looking more in depth at some of the other firm level variables in our data set suggests that productivity improvements go beyond spare capacity utilization.

In Table 6 we report the results of a difference-in difference analysis where we compare the growth in gross investment, the growth in employment, the growth in $\mathrm{R} \& \mathrm{D}^{29}$ and the change in wages between firms in $\mathrm{AD}$ protection cases and firms in termination cases, which are arguably the most similar firms to the protected firms. We find that protected firms have lower growth in employment, a higher growth in investment in $\mathrm{R} \& \mathrm{D}$, higher wage growth and a higher growth in gross investment after AD protection than non-protected firms. All this suggests that protected firms are downsizing relatively more in terms of employment, or alternatively replacing unskilled by more skilled type of workers, are investing relatively more in tangible and intangible fixed assets which implies that the capital intensity of production is going up possibly resulting in higher value added or high quality products and are paying more to their workers which could either be a reflection of rentsharing or of an alteration of the skill mix at the firm level.

Unfortunately, our firm level dataset only allows us to verify a limited number of channels through which productivity can be improved. Other effects are likely to be at play. Recent work by Bernard et al. (2006) points at evidence of product switching in industries that face tough import competition. They find that trade shocks often coincide with firms dropping uncompetitive products. While we can not verify this in our dataset, it is clear that such a change in the product mix is likely to result in higher productivity. Also, there is some limited evidence that firms in import-competing industries engage in outsourcing by moving non-skilled activities abroad and shifting local

\footnotetext{
${ }^{29}$ Researchers have pointed out that antidumping protection often targets R\&D-intensive industries (Niels, 2000).
} 
employment more towards skilled workers as argued by Feenstra \& Hanson, (1999). This would also be consistent with shedding unskilled labor at home and investment in tangible and intangible assets.

\section{Conclusion}

This paper provides empirical evidence that temporary AD protection is associated with productivity gains for the domestic import-competing firms. For this purpose we identified around 4,800 European producers affected by AD cases. While some firms were granted protection, others were not. Our results indicate that $\mathrm{AD}$ protection is associated with an increase in total factor productivity for protected firms compared to firms that did not receive AD protection. The increase in long-run productivity levels depends on the control group that was used and on the single versus multi-product nature of the firms included in the analysis with estimates of long-run productivity improvements ranging between 5\% and 13\%. Our estimations controlled for potential price and selection effects of $\mathrm{AD}$ rulings.

The effect of protection on firm level productivity that we find is subject to firm heterogeneity with stronger effects on the productivity of 'laggard firms' in the industry. These empirical results are consistent with recent theoretical findings that have pointed at the relationship between product market competition, temporary tariff protection and domestic firms' incentives to become more efficient (Miyagiwa and Ohno, 1995; Aghion et al, 2005, Boone, 2000). Finally, given that evidence suggests that the productivity improvements are not driven by prices we are inclined to believe that they are permanent in nature. This is also supported by the evidence of firm-level restructuring that we find.

An interesting further line of research would be to engage in more in depth industry analysis to explore the channels through which productivity improvements at the firm level are made. Our results indicate that as a response to AD protection domestic firms on average reduce employment and increase their spending on tangible and intangible assets including R\&D. But we recognize that there are many other channels through which productivity improvements can come about such as 
product-switching and outsourcing that unfortunately our data do not allow us to verify. Also different industries may respond differently. This would call for detailed industry level studies which could help us to understand better how firms respond under temporary protection. 


\begin{tabular}{|c|c|c|c|c|c|c|c|c|c|}
\hline $\begin{array}{l}\text { Year of } \\
\text { AD } \\
\text { Initiation }\end{array}$ & Product & $\begin{array}{l}\text { \# HS } \\
\text { per } \\
\text { case }\end{array}$ & $\begin{array}{l}\text { NACE } \\
\text { rev.1 }\end{array}$ & $\begin{array}{l}\text { Decision } \\
\text { (Duty/ } \\
\text { Undertak/Termination) }\end{array}$ & $\begin{array}{l}\text { Year of } \\
\text { AD } \\
\text { Decision }\end{array}$ & $\begin{array}{l}\text { Average } \\
\text { Duty }^{\left(b^{b}\right)} \\
\text { (\%) }\end{array}$ & $\begin{array}{l}\text { Expiry } \\
\text { Review }^{\odot} \\
\text { Initiation }\end{array}$ & $\begin{array}{l}\text { Decision } \\
\text { of } \\
\text { Review }\end{array}$ & Defendants \\
\hline \multirow[t]{7}{*}{1996} & Cotton fabrics-unbleached & 17 & 1720 & $\mathrm{~T}$ & 1997 & 0 & & & $\begin{array}{l}\text { China, Egypt, India, Indonesia, Pakist‘ } \\
\text { Turkey }\end{array}$ \\
\hline & Synthetic fibre ropes & 4 & 1752 & $\mathrm{~T}$ & 1997 & 0 & & & India \\
\hline & $\begin{array}{l}\text { Briefcases, schoolbags, } \\
\text { luggage \& travel goods }\end{array}$ & 6 & 1920 & $\mathrm{~T}$ & 1997 & 0 & & & China \\
\hline & Seamless pipes and tubes & 5 & 2722 & $\mathrm{D} / \mathrm{U}^{(\mathrm{a})}$ & 1997 & 21 & 2002 & $\mathrm{D}$ & $\begin{array}{l}\text { Russia, Czech. Republic, Romania, } \\
\text { Slovak Republic, Poland, Hungary }\end{array}$ \\
\hline & Bed linen (cotton type) & 5 & 1740 & $\mathrm{D}$ & 1997 & 16 & 2002 & $\mathrm{~T}$ & Egypt, India, Pakistan \\
\hline & Stainless steel fasteners & 7 & 2874 & $\mathrm{D}$ & 1998 & 32 & & & $\begin{array}{l}\text { China, India, Malaysia, Korea, Taiwar } \\
\text { Thailand }\end{array}$ \\
\hline & Ferro-silicomanganese & 1 & 2710 & $\mathrm{D}$ & 1998 & $\begin{array}{l}58.3 \text { ecu per } \\
\text { ton }\end{array}$ & & & China \\
\hline \multirow[t]{10}{*}{1997} & Fax machines & 1 & 3220 & $\mathrm{D}$ & 1998 & 43 & & & $\begin{array}{l}\text { China, Japan, S-Korea, Malaysia, } \\
\text { Singapore, Taiwan, Thailand }\end{array}$ \\
\hline & Potassium permanganate & 1 & 2413 & $\mathrm{D}$ & 1998 & 21 & & & India, Ukraine \\
\hline & Polysulphide polymers & 1 & 2417 & $\mathrm{D}$ & 1998 & 13 & & & USA \\
\hline & Synthetic fibre ropes & 4 & 1752 & $\mathrm{D}$ & 1998 & 82 & 2003 & $\mathrm{D}$ & India \\
\hline & Monosodium glutamate & 1 & 2441 & $\mathrm{~T}$ & 1998 & 0 & & & Brazil, USA, Vietnam \\
\hline & Cotton fabrics & 15 & 1720 & $\mathrm{~T}$ & 1998 & 0 & & & $\begin{array}{l}\text { China, Egypt, India, Indonesia, Pakist: } \\
\text { Turkey }\end{array}$ \\
\hline & Strips of iron or non-alloy st & 4 & 2732 & $\mathrm{~T}$ & 1998 & 0 & & & Russia \\
\hline & \begin{tabular}{l|l} 
Synthetic fibre ropes \\
\end{tabular} & 4 & 1752 & $\mathrm{~T}$ & 1998 & 0 & & & S-Korea \\
\hline & Unwrought magnesium & 2 & 2745 & $\mathrm{D}$ & 1998 & 32 & & & China \\
\hline & Stainless steel bright bars & 4 & 2731 & $\mathrm{D}$ & 1998 & 25 & & & India \\
\hline
\end{tabular}




\begin{tabular}{|c|c|c|c|c|c|c|c|c|c|}
\hline & Thiourea dioxide & 2 & 2414 & $\mathrm{~T}$ & 1998 & 0 & & & China \\
\hline & Hardboard & 10 & 2020 & $\mathrm{D} / \mathrm{U}$ & 1999 & 16 & & & Japan, Korea, Malaysia, China, Taiwa \\
\hline & Bicycles & 2 & 3542 & $\mathrm{D}$ & 1999 & 18 & & & $\begin{array}{l}\text { Brazil, Bulgaria, Estonia, Latvia, } \\
\text { Lithuania, Poland, Russia }\end{array}$ \\
\hline & $\begin{array}{l}\text { Electrolytic alumin. } \\
\text { Capacitators }\end{array}$ & 3 & 3210 & $\mathrm{~T}$ & 1999 & 0 & & & Taiwan \\
\hline & Woven glass fibre & 1 & 1720 & $\mathrm{~T}$ & 1998 & 0 & & & USA, Thailand \\
\hline \multirow[t]{7}{*}{1998} & Polypropylene binder & 1 & 1752 & $\mathrm{D} / \mathrm{U}$ & 1999 & 26 & & & Japan \\
\hline & Steel stranded rope \& cables & 1 & 2873 & $\mathrm{D} / \mathrm{U}$ & 1999 & 45 & 2004 & $\mathrm{~T}$ & Poland, Czech. Republic, Hungary \\
\hline & \begin{tabular}{l|l} 
Stainless steel wire \\
\end{tabular} & 4 & 2734 & $\mathrm{D} / \mathrm{U}$ & 1999 & 56 & & & China, India, South Africa, Ukraine \\
\hline & Steel stranded rope \& cables & 1 & 2873 & $\mathrm{D} / \mathrm{U}$ & 1999 & 44 & & & India, Korea \\
\hline & Polyester filament yarn & 4 & 2470 & $\mathrm{~T}$ & 1999 & 0 & & & Hungary, Mexico, Poland \\
\hline & Stainless steel heavy plates & 1 & 2710 & $\mathrm{~T}$ & 1999 & 0 & & & Korea, India \\
\hline & Seamless pipes and tubes & 2 & 2722 & $\mathrm{D} / \mathrm{U}$ & 2000 & 31 & & & Slovenia, South Africa \\
\hline
\end{tabular}

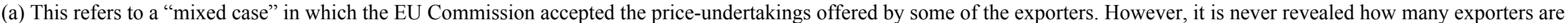
granted undertakings.

(b) The average duty is the country wide duty that applies to "all other exporting producers". Exporters that co-operate in the EU AD investigation often get a lower duty.

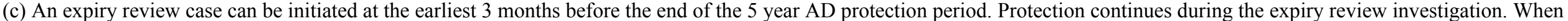
the expiry review is affirmative, the AD protection is extended for another 5 year period.

(d) This case consists of 3 cases belonging to the same sector: "Briefcases and Schoolbags"; "Luggage and Travel Goods"; "Leather Handbags". 
Table 2: Difference-in-Difference Estimates of AD Protection on Firm Level TFP

\begin{tabular}{|c|c|c|c|c|c|}
\hline CONTROL GROUP & \multicolumn{3}{|c|}{ TERMINATIONS } & \multicolumn{2}{|c|}{ MATCHED } \\
\hline & (1) & (2) & (3) & (4) & (5) \\
\hline Deflator & PPI 4-digit & Unit Values & PPI 4-digit & PPI 4-digit & PPI 4-digit \\
\hline $\mathrm{tfp}_{\mathrm{it}-1}$ & - & - & $\begin{array}{l}0.813 * * * \\
(0.007)\end{array}$ & - & $\begin{array}{l}0.835^{* * *} \\
(0.004)\end{array}$ \\
\hline AD- Effect & $\begin{array}{l}0.07 * * * \\
(0.009)\end{array}$ & $\begin{array}{l}0.076^{* * *} \\
(0.013)\end{array}$ & $\begin{array}{l}0.019 * * * \\
(0.005)\end{array}$ & $\begin{array}{l}0.128 * * * \\
(0.010)\end{array}$ & $\begin{array}{l}0.017 * * * \\
(0.005)\end{array}$ \\
\hline Ever-protection & $\begin{array}{l}-0.052 * * \\
(0.018)\end{array}$ & $\begin{array}{l}0.019 \\
(0.021)\end{array}$ & $\begin{array}{l}0.002 \\
(0.006)\end{array}$ & $\begin{array}{l}-0.339 * * * \\
(0.015)\end{array}$ & $\begin{array}{l}-0.036^{* * * *} \\
(0.005)\end{array}$ \\
\hline Year effects & Yes & Yes & Yes & Yes & Yes \\
\hline Location effects & Yes & Yes & Yes & Yes & Yes \\
\hline Location X Year effects & Yes & Yes & Yes & Yes & Yes \\
\hline $\mathrm{R}^{2}$ & 0.26 & 0.31 & 0.73 & 0.3 & 0.78 \\
\hline \# observations & 40,686 & 35,986 & 36,014 & 68,951 & 59,781 \\
\hline
\end{tabular}

Notes: $* * * / * *$ refer to respectively significance at the $1 \% / 5 \%$ level, (ii) Heteroskedastic robust standard errors between brackets.

Table 3: Difference-in-difference of AD protection on EU Prices

\begin{tabular}{|c|c|c|c|c|}
\hline & $(1)$ & $(2)$ & (3) & $(4)$ \\
\hline Ln price ${ }_{\mathrm{kt}-1}$ & - & $0.969(0.012)^{* * *}$ & - & $0.970(0.012)^{* * *}$ \\
\hline EVER-PROTECT & $-1.25(0.467)^{* * *}$ & $-0.017(0.026)$ & $-1.25(0.470)^{* * *}$ & $-0.017(0.027)$ \\
\hline TIME & $-0.015(0.103)$ & $0.002(0.0118)$ & $-0.015(0.104)$ & $0.0023(0.0119)$ \\
\hline AD-PRICE-EFFECT & $0.258(0.180)$ & $-0.015(0.018)$ & - & - \\
\hline $\begin{array}{l}\text { PRICE-EFFECT x year } 1 \\
\text { After protection }\end{array}$ & - & - & $0.167(0.172)$ & $-0.060(0.042)$ \\
\hline AD-PRICE-EFFECT $x$ year 2 & - & - & $0.120(0.186$ & $-0.059(0.094)$ \\
\hline AD-PRICE-EFFECTx year 3 & - & - & $0.272(0.201)$ & $0.059(0.088)$ \\
\hline AD-PRICE-EFFECT x year 4 & - & - & $0.335(0.192)^{*}$ & $0.052(0.0306)^{*}$ \\
\hline AD-PRICE-EFFECTx year 5 & - & - & $0.342(0.189)^{*}$ & $-0.0003(0.017)$ \\
\hline AD-PRICE-EFFECT $\mathrm{x}$ year 6 & - & - & $0.436(0.258)$ & $-0.103(0.075)$ \\
\hline AD-PRICE-EFFECT x year 7 & - & - & $0.055(0.395)$ & $-0.021(0.021)$ \\
\hline Const & $1.83(0.403)^{* * *}$ & $0.049(0.027)^{*}$ & $1.833(0.408)^{* * *}$ & $0.0488(0.028) *$ \\
\hline \#obs & 431 & 399 & 431 & 399 \\
\hline $\mathrm{R}^{2}$ & 0.204 & 0.96 & 0.205 & 0.96 \\
\hline
\end{tabular}

Note: t-statistics between brackets; $* * * / * * / *$ represents significance at the $1 \% ; 5 \%$ and $10 \%$ respectively 
Table 4: Distance-to-the-Frontier and Single versus Multiple Product Firms

\begin{tabular}{|c|c|c|c|c|c|c|c|}
\hline \multirow[t]{2}{*}{ CONTROL GROUP } & \multicolumn{4}{|c|}{ TERMINATIONS } & \multicolumn{3}{|c|}{ MATCHED } \\
\hline & $\begin{array}{l}(1) \\
\text { TFP } \\
\text { levels }\end{array}$ & $\begin{array}{l}\text { (2) } \\
\text { TFP levels }\end{array}$ & $\begin{array}{l}(3) \\
\text { Single } \\
\text { products }\end{array}$ & $\begin{array}{l}\text { (4) } \\
\text { Multiple } \\
\text { Product }\end{array}$ & $\begin{array}{l}(5) \\
\text { TFP } \\
\text { levels }\end{array}$ & $\begin{array}{l}(6) \\
\text { Single } \\
\text { products }\end{array}$ & $\begin{array}{l}(7) \\
\text { Multiple } \\
\text { products }\end{array}$ \\
\hline Deflator & PPI 4-digit & Unit values & PPI 4-digit & PPI 4-digit & PPI 4-digit & PPI 4-digit & PPI 4-digit \\
\hline $\mathrm{tfp}_{\mathrm{it}-1}$ & $\begin{array}{l}0.703 * * * \\
(0.010)\end{array}$ & $\begin{array}{l}0.798 * * * \\
(0.005)\end{array}$ & $\begin{array}{l}0.679 * * * \\
(0.012)\end{array}$ & $\begin{array}{l}0.711 * * * \\
(0.030)\end{array}$ & $\begin{array}{l}0.777 * * * \\
(0.006)\end{array}$ & $\begin{array}{l}0.752 * * * \\
(0.008)\end{array}$ & $\begin{array}{l}0.747 * * * \\
(0.021)\end{array}$ \\
\hline AD Effect & $\begin{array}{l}0.063 * * * \\
(0.009\end{array}$ & $\begin{array}{l}0.075 * * * \\
(0.009)\end{array}$ & $\begin{array}{l}0.065 * * * \\
(0.011)\end{array}$ & $\begin{array}{l}0.013 \\
(0.030)\end{array}$ & $\begin{array}{l}0.083 * * * \\
(0.007)\end{array}$ & $\begin{array}{l}0.083 * * * \\
(0.010)\end{array}$ & $\begin{array}{l}0.044^{*} \\
(0.028)\end{array}$ \\
\hline AD Effect X Distance & $\begin{array}{l}-0.110 * * * \\
(0.028)\end{array}$ & $\begin{array}{l}-0.085 * * * \\
(0.029)\end{array}$ & $\begin{array}{l}-0.116 * * * \\
(0.034)\end{array}$ & $\begin{array}{l}0.053 \\
(0.126)\end{array}$ & $\begin{array}{l}-0.287 * * * \\
(0.025)\end{array}$ & $\begin{array}{l}-0.305 * * * \\
(0.034)\end{array}$ & $\begin{array}{l}-0.165^{*} \\
(0.11) \\
\end{array}$ \\
\hline Distance & $\begin{array}{l}0.706 * * * \\
(0.037)\end{array}$ & $\begin{array}{l}0.430 * * * \\
(0.030)\end{array}$ & $\begin{array}{l}0.785 * * * \\
(0.043)\end{array}$ & $\begin{array}{l}0.589 * * * \\
(0.143)\end{array}$ & $\begin{array}{l}0.530 * * * \\
(0.026)\end{array}$ & $\begin{array}{l}0.587 * * * \\
(0.036)\end{array}$ & $\begin{array}{l}0.535 * * * \\
(0.094)\end{array}$ \\
\hline Ever protection & $\begin{array}{l}-0.020 * * * \\
(0.006)\end{array}$ & $\begin{array}{l}-0.034 * * * \\
(0.006)\end{array}$ & $\begin{array}{l}-0.036 * * * \\
(0.008)\end{array}$ & $\begin{array}{l}0.024 \\
(0.017) \\
\end{array}$ & $\begin{array}{l}-0.058 * * * \\
(0.005)\end{array}$ & $\begin{array}{l}-0.066^{* * *} \\
(0.008)\end{array}$ & $\begin{array}{l}-0.018 \\
(0.023) \\
\end{array}$ \\
\hline Year effects & Yes & Yes & Yes & Yes & Yes & Yes & Yes \\
\hline Location effects & Yes & Yes & Yes & Yes & Yes & Yes & Yes \\
\hline Location X Year effects & Yes & Yes & Yes & Yes & Yes & Yes & Yes \\
\hline $\mathrm{R}^{2}$ & 0.74 & 0.80 & 0.73 & 0.72 & 0.78 & 0.77 & 0.72 \\
\hline \# observations & 36,014 & 31,012 & 21,315 & 4,732 & 59,781 & 36,249 & 6,335 \\
\hline
\end{tabular}

Note: $* * * * * *$ refer to respectively significance at the $1 \% / 5 \%$ level; Heteroskedastic robust standard errors between brackets. 
Table 5: Robustness checks

\begin{tabular}{|c|c|c|c|c|c|}
\hline \multirow[t]{3}{*}{ CONTROL GROUP } & \multicolumn{5}{|c|}{ TERMINATIONS } \\
\hline & \multicolumn{2}{|c|}{ BERTRAND et al. (2004) correction } & \multicolumn{2}{|c|}{$\begin{array}{l}\text { TREFLER (2004) } \\
\text { Long Run differences }\end{array}$} & \multirow{2}{*}{$\begin{array}{l}\text { Year-By-Year } \\
\text { (5) TFP level }\end{array}$} \\
\hline & (1) TFP level & (2) TFP level & $\begin{array}{l}\text { (3) TFP } \\
\text { growth }\end{array}$ & (4) TFP growth & \\
\hline AD Effect & $\begin{array}{l}0.132 * * * \\
(0.023)\end{array}$ & $\begin{array}{l}0.169 * * * \\
(0.027)\end{array}$ & $\begin{array}{l}0.016 * * \\
(0.009)\end{array}$ & $\begin{array}{l}0.059 * * * \\
(0.010)\end{array}$ & - \\
\hline AD Effect X Distance & - & $\begin{array}{l}-0.193 * * * \\
(0.076)\end{array}$ & $\begin{array}{l}0.004 \\
(0.008)\end{array}$ & $\begin{array}{l}-0.162 * * * \\
(0.022)\end{array}$ & - \\
\hline Distance & - & $\begin{array}{l}2.379 * * * \\
(0.069)\end{array}$ & - & $\begin{array}{l}0.043 * * * \\
(0.018)\end{array}$ & - \\
\hline Ever protection & $\begin{array}{l}-0.107 * * * \\
(0.026)\end{array}$ & $\begin{array}{l}-0.135^{* * *} \\
(0.019)\end{array}$ & - & $\begin{array}{l}0.003 \\
(0.008)\end{array}$ & $\begin{array}{l}-0.026 \\
(0.018)\end{array}$ \\
\hline AD Effect after 1 year & - & - & - & - & $\begin{array}{l}0.027 * * * \\
(0.007)\end{array}$ \\
\hline AD Effect after 2 years & - & - & - & - & $\begin{array}{l}0.045^{* * * *} \\
(0.009)\end{array}$ \\
\hline AD Effect after 3 years & - & - & - & - & $\begin{array}{l}0.050 * * * \\
(0.011)\end{array}$ \\
\hline AD Effect after 4 years & - & - & - & - & $\begin{array}{l}0.048 * * * \\
(0.012)\end{array}$ \\
\hline AD Effect after 5 years & - & - & - & - & $\begin{array}{l}0.044 * * * \\
(0.010)\end{array}$ \\
\hline AD Effect X Distance & Yes & Yes & Yes & Yes & Yes \\
\hline Location effects & Yes & Yes & Yes & Yes & Yes \\
\hline Location X Year effects & Yes & Yes & Yes & Yes & Yes \\
\hline $\mathrm{R}^{2}$ & 0.31 & 0.64 & 0.05 & 0.06 & 0.26 \\
\hline \# observations & 5,563 & 5,563 & 5,5563 & 5,563 & 40,686 \\
\hline
\end{tabular}

Note: (i) $* * * * *$ refer to respectively significance at the $1 \% / 5 \%$ level; Heteroskedastic robust standard errors between brackets. 
Département des Sciences Économiques de l'Université catholique de Louvain

Institut de Recherches Économiques et Sociales

Place Montesquieu, 3

1348 Louvain-la-Neuve, Belgique 